\title{
EVALUATION OF MILK PRODUCTION OF AN ALGERIAN LOCAL RABBIT POPULATION RAISED IN THE TIZI-OUZOU AREA(KABYLIA)
}

\author{
Zerrouki N.", Lebas F. ${ }^{\dagger}$, Berchiche M.*, Bolet G. \\ *University of Tizi Ouzou, Laboratory of Physiology and Nutrition, BP 17 RP, \\ Tizi-Ouzou, Algeria. \\ † Cuniculture, 87a Chemin de Lassère, 31450 CorronsaC, France. \\ *INRA, SAGA, BP 27. 31326 Castanet-Tolosan Cedex, France.
}

\begin{abstract}
In order to characterize the does of a local Kabylian rabbit population raised in Algeria, a study of their milk production was carried out in the experimental rabbitry of the Tizi-Ouzou University. Milk production of does was measured every day during the 21 days following 299 parturitions by weighing each litter before and after the single daily suckling. The calculated parameters were the quantity of milk produced per day, per week and the total quantity produced in 21 days, as well as the intake of milk per young rabbit. The analysis concerned the effects of the parity order (4 classes: 1 to 4-and-more) and of the average number of young rabbits suckled per litter (7 classes: from 2-3 kits to more-than-8). During the 21 days of controlled lactation, the average litter size was $5.6 \pm 2.3$. The rabbit does of the local Kabylian population produced on average $2180 \pm 719 \mathrm{~g}$ in 21 days, which is $104 \mathrm{~g}$ of milk/day. The milk intake of young rabbits increased from $12.6 \mathrm{~g} / \mathrm{day} / \mathrm{kit}$ during the $1^{\text {st }}$ week, to $27.2 \mathrm{~g} /$ day during the $3^{\text {rd }}$ week of lactation. The number of young per litter influenced the does' milk production very significantly: $62.8 \mathrm{~g} / \mathrm{d}$ for 2 to 3 young per litter, and up to $127-131 \mathrm{~g} /$ day for more than 6 young, although milk production available per kit and per day decreased linearly with the number of kits in the litter for each of the 3 weeks considered. On the other hand, the average milk production expressed as quantity available per kit and per day was not significantly affected by the parity order: $20-21 \mathrm{~g} / \mathrm{kit} /$ day on average for the $0-21$ day period.
\end{abstract}

Key words: rabbit, local population, Algeria, milk production.

\section{INTRODUCTION}

Characterisation of a local population must take into account all the different aspects involved in the achievement of average performance: growth parameters,

Correspondence: N. Zerrouki

E-mail: nacera_zerrouki@yahoo.fr 
fertility, litter size at parturition, average numerical productivity of these animals per time unit, etc... The ability of females to produce milk is one of the main factors involved in after-birth growth rate of young (BASELGa et al., 1982) and in the determination of litter size at weaning.

The present study is part of the work started some years ago to characterise a local Algerian rabbit population raised in Kabylia (Zerrouki et al., 2001; 2002). The main objective of this study was to determine the evolution of milk production during the 3 weeks following parturition, and of the effects of litter size and parturition order on milk production.

\section{MATERIALS AND METHODS}

This study was conducted in the experimental rabbitry of Tizi-Ouzou University (100 km east of Algiers) between November 1998 and July 2002. The rabbit does used in this study were descended from males and females of the local rabbit population collected from farms in the Tizi-Ouzou (Kabylia region) in 1998 and managed in a closed population with one generation per year (ZERrouKI et al., 2004). The 299 lactations analysed in the study were obtained from 116 does, corresponding to 5 generations: 20 to 32 does gave usable data for each generation.

\section{General management}

The capacity of the rabbitry enabled 46 does to be reared at the same time, in individual all wire mesh cages placed on one single level. All rabbits of the $1^{\text {st }}$ and $2^{\text {nd }}$ generation received ad libitum the same commercial pelleted diet: 16.6\% crude protein and $12.3 \%$ crude fibre. Water was always available from automatic drinkers. Rabbits of the $3^{\text {rd }}, 4^{\text {th }}$ and $5^{\text {th }}$ generation received under the same conditions another pelleted diet formulated in the laboratory and containing $17.8 \%$ crude protein and $14.4 \%$ crude fibre. Lighting duration was natural for the first two generations and controlled at $16 \mathrm{~h}$ for the other generations $\left(3^{\text {rd }}\right.$ to $\left.5^{\text {th }}\right)$. Females were presented to a male not earlier than 10 days after parturition, and then daily until effective mating. 
A nest box was placed in the cage 3-4 days before the expected day of parturition and remained there for the 21 days of control following parturition. Litters were weighed and litter size determined immediately after birth and every day subsequently. No standardisation of litters was practised.

After parturition and controls, does had access to the nest box only once a day in the morning for 10-15 minutes. Milk production was estimated as the increase in litter weight between the 2 weight determinations made immediately before and after the daily suckling. Weaning age was 28 days.

\section{Statistical analysis}

Recorded data were analysed according to a factorial experimental design with the parity order (4 classes: 1 to 4 -and-more), average number of kits per litter ( 7 classes: from 2-3 kits to more-than-8.0) and number of generation (5 classes), as main effects.

All $2 \times 2$ interactions were included in the statistical model of analysis (GLM procedure of SAS, 1988). The generation effect, although not shown, was included in the model.

\section{RESULTS AND DISCUSSION}

The effect of the "generation" factor are not presented here because they include too many non-separable effects: for example, true generation effect, year of observation (climatic variations), and management variations concerning the type of feeding or the rhythm of lighting. For this reason the apparent effect of the "generation" factor is impossible to interpret and also impossible to reproduce. Nevertheless its inclusion in the statistical model was of great interest since it reduced the residual variance and facilitated the interpretation of the other controlled factors. None of the interactions was significant. Thus only the main effects i.e. parity order and average number of suckled kits are presented below. 


\section{Does milk production}

The production obtained in 21 days was $2180 \mathrm{~g}$, corresponding to an average daily production of $104 \mathrm{~g} /$ day. Milk production increased with weeks of lactation: 471,768 and $940 \mathrm{~g}$ for the $1^{\text {st }}, 2^{\text {nd }}$ and the $3^{\text {rd }}$ lactation weeks, respectively (Table 1 ). The daily production increased continuously during the 21 days of observation from $42 \mathrm{~g}$ on day 1 , up to $147 \mathrm{~g}$ on day 21 (Figure 1). This form of evolution is identical to the classical description of rabbit doe milk production during the first 3 weeks (LEBAs, 2000).

Table 1: Average milk production observed during the suckling period with Kabylian rabbit does.

\begin{tabular}{|c|c|c|c|}
\hline & $\mathrm{N}^{\circ}$ obs. & Mean & Standard deviation \\
\hline \multicolumn{4}{|l|}{ Total milk production (g) } \\
\hline week 1 & 299 & 471 & 186 \\
\hline week 2 & 299 & 768 & 264 \\
\hline week 3 & 299 & 940 & 320 \\
\hline Production in 21 days & 299 & 2180 & 719 \\
\hline \multicolumn{4}{|c|}{ Daily milk intake of kits (g/day/kit) } \\
\hline week 1 & 299 & 12.6 & 4.4 \\
\hline week 2 & 299 & 21.8 & 7.4 \\
\hline week 3 & 299 & 27.2 & 9.8 \\
\hline Average for the 21 days & 299 & 20.5 & 6.6 \\
\hline \multicolumn{4}{|c|}{ Number of suckled young (kits/litter) } \\
\hline week 1 & 299 & 5.79 & 2.33 \\
\hline week 2 & 299 & 5.52 & 2.31 \\
\hline week 3 & 299 & 5.49 & 2.32 \\
\hline Average for the 21 days & 299 & 5.60 & 2.90 \\
\hline
\end{tabular}




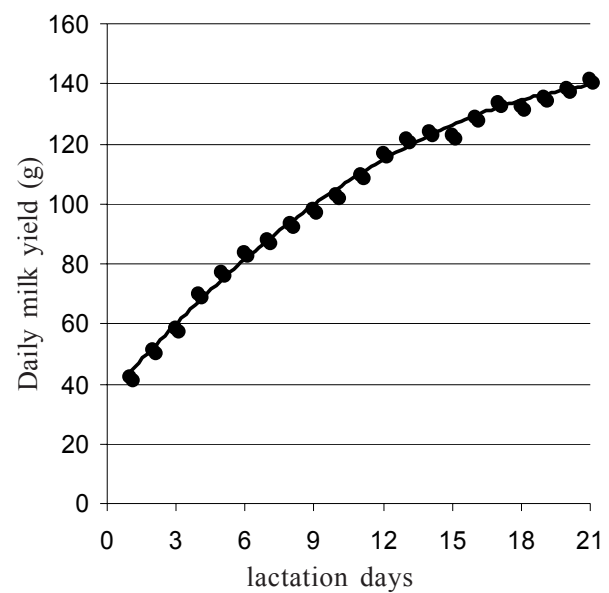

Figure 1: Evolution of daily milk production.

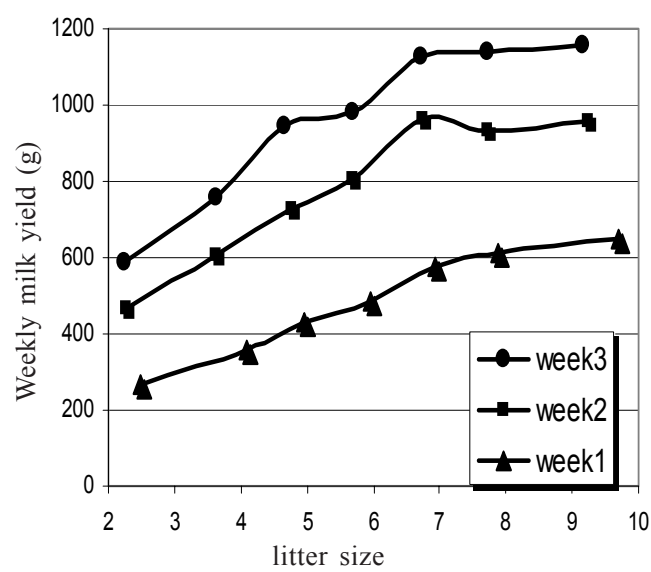

Figure 2: Weekly milk production of females, according to litter size.

The total milk production obtained in 21 days with does of this local Kabylian population was slightly higher than that described by Khalil (1998) in Egypt for Baladi Red (2150 g) and Baladi Black (2180 g) females. It was just lower than the $2640 \mathrm{~g}$ described by the same author for the Giza White, but clearly lower than the $3567 \mathrm{~g}$ observed by Mohamed and Szendrõ (1992) for litters of 6 kits in a Californian line selected in Hungary. This relatively low milk production can be related to the relatively small adult weight (2.8 to $3.0 \mathrm{~kg}$ ) of this local population (Zerrouki et al., 2001, 2004) and partly to the hot climate which usually reduces the feed intake and milk production of does (FERNÁNDEZ-CARMONA et al., 2003).

\section{Effect of litter size}

Milk production increased with the litter size (Table 2) as it is generally observed in the rabbit (LeBAs, 2000). Nevertheless, it must be emphasised that maximum milk production capacity of does was obtained in response to a litter of 7 kits. An increase in litter size above 7 was not able to stimulate a corresponding increase in milk production. During the $1^{\text {st }}$ week, milk production increased up to 8 kits per litter, but during the last 2 weeks of the observation period, maximum milk production was clearly obtained with litters of 7 young (Figure 2).

Previous works, developed with different lines of selected Californian does, have observed a similar increase of the doe milk yield with litter size, but until 10 kits 
(Mohamed and Szendrõ 1992) or 11 kits (Lebas, 1987). Thus, this limited ability to increase total milk production when litter size is higher than 7 should be considered as a possible characteristic of this local Kabylian population.

Despite the increase in does' milk production with litter size, the quantity of milk available for each young decreased quite linearly with litter size increase (Table 2). This highly significant decrease was observed for each of the 3 weeks of observation (Figure 3), and it was observed that, as it was expected, the regression slope seemed to increase with the week of lactation.

\section{Effect of the parity order}

In the conditions of this study, litter size was not significantly affected by order of parturition (Table 3), while milk production increased with the parturition number. Such a variation in milk production with parturition order was previously described e.g. for primiparous does compared with multiparous ones (Aвоu Elezz et al, 1981) and/or as an increase with the parturition order up to 7 by MCNitT and LukEFAHR (1990).

Table 2: Effect of the litter size on daily milk production (means \pm mean standard error).

\begin{tabular}{cccc}
\hline $\begin{array}{c}\text { Litter } \\
\text { size }\end{array}$ & $\begin{array}{c}\text { Number of litters } \\
\text { observed }\end{array}$ & $\begin{array}{c}\text { Daily milk production } \\
\text { of doe }(\mathrm{g})\end{array}$ & $\begin{array}{c}\text { Daily milk intake of young } \\
(\mathrm{g} / \text { day/kit })\end{array}$ \\
\hline$[2-3]$ & 58 & $62.8^{\mathrm{a}} \pm 3.0$ & $27.9^{\mathrm{a}} \pm 1.0$ \\
\hline $3-4]$ & 34 & $82.1^{\mathrm{b}} \pm 3.2$ & $22.7^{\mathrm{b}} \pm 0.9$ \\
{$[4-5]$} & 39 & $100.2^{\mathrm{c}} \pm 3.8$ & $21.2^{\mathrm{b}} \pm 0.8$ \\
{$[5-6]$} & 45 & $108.4^{\mathrm{c}} \pm 3.4$ & $18.9^{\mathrm{c}} \pm 0.6$ \\
{$[6-7]$} & 49 & $127.0^{\mathrm{d}} \pm 3.5$ & $18.8^{\mathrm{c}} \pm 0.5$ \\
{$[7-8]$} & 40 & $128.0^{\mathrm{d}} \pm 3.8$ & $16.6^{\mathrm{d}} \pm 0.5$ \\
$>8$ & 34 & $131.3^{\mathrm{d}} \pm 4.5$ & $14.2^{\mathrm{e}} \pm 0.5$ \\
Significance & & $* * *$ & $* * *$ \\
\hline
\end{tabular}

Means within a column with different superscript differ $(P<0.05)$.

NS: not significant. $* * * P<0.001$ 


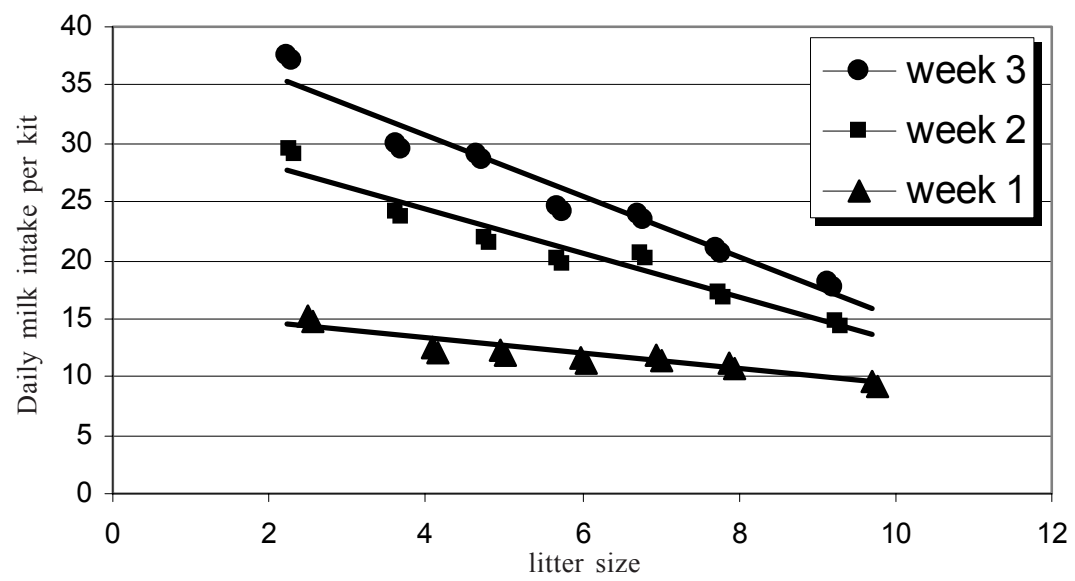

Figure 3: Evolution of kit's daily milk intake with litter size increase.

In the present study, the effect was mainly a consequence of the increase in milk production during the first week of lactation (production of older does 30\% higher than that of primiparous does). Nevertheless, because of slight numerical

Table 3: Litter size and milk production of Kabylian does in relation to parturition order (means \pm mean standard error).

\begin{tabular}{|c|c|c|c|c|c|c|}
\hline & \multicolumn{4}{|c|}{ Parity order } & \multirow[b]{2}{*}{ Significance } \\
\hline & & 1 & 2 & 3 & $\$ 4$ & \\
\hline \multicolumn{2}{|c|}{ Number of observations } & 126 & 81 & 58 & 34 & \\
\hline \multicolumn{2}{|l|}{ Litter size } & $5.39 \pm 0.19$ & $5.60 \pm 0.25$ & $5.99 \pm 0.34$ & $5.69 \pm 0.43$ & NS \\
\hline \multicolumn{2}{|c|}{$\begin{array}{l}\text { Doe's milk production } \\
\text { in } 21 \text { days }(\mathrm{g})\end{array}$} & $2069^{\mathrm{a}} \pm 56$ & $2214^{\mathrm{ab}} \pm 77$ & $2268^{a b} \pm 106$ & $2356^{\mathrm{b}} \pm 153$ & $*$ \\
\hline \multicolumn{2}{|c|}{$\begin{array}{l}\text { Daily milk intake of } \\
\text { young }(g / \text { day/kit) }\end{array}$} & $20.0 \pm 0.51$ & $21.3 \pm 0.78$ & $20.3 \pm 1.07$ & $20.9 \pm 0.85$ & NS \\
\hline \multirow{3}{*}{$\begin{array}{l}\text { Doe's milk } \\
\text { production } \\
\text { (g) during } \\
\text { each week }\end{array}$} & Week 1 & $416^{a} \pm 13$ & $479^{\mathrm{ab}} \pm 19$ & $535^{\mathrm{bc}} \pm 28$ & $548^{c} \pm 42$ & $* *$ \\
\hline & Week 2 & $732^{a} \pm 21$ & $779^{\mathrm{ab}} \pm 28$ & $789^{\mathrm{ab}} \pm 37$ & $833^{c} \pm 56$ & $*$ \\
\hline & Week 3 & $922 \pm 27$ & $955 \pm 36$ & $944 \pm 45$ & $969 \pm 61$ & NS \\
\hline
\end{tabular}

Means within a row with different superscript differ $(P<0.05)$.

NS: not significant. ${ }^{*} P<0.05 ; * * P<0.01$. 
differences in litter size with parturition number in favour of multiparous does, the average milk quantity available per kit and per day was not significantly affected by parturition number, despite the total increase in milk production. For this reason, an average milk production of $20.5 \mathrm{~g}$ per day and per kit between the $1^{\text {st }}$ and $21^{\text {st }}$ day of lactation may be considered as a characteristic of the Kabylian rabbit population under study, regardless of parturition order.

\section{CONCLUSION}

As a conclusion it can be considered that the characteristics of the local Kabylian rabbit population in relation to milk production are as follows:

-an average milk production of $2180 \mathrm{~g}$ in 21 days, i.e. $104 \mathrm{~g}$ per day

- an increase of milk production with litter size, up to litters of 7 kits, i.e. a maximum milk production of about $2700 \mathrm{~g}$ in 21 days.

- a milk production capacity independent of parity order when it is expressed as daily amount available per kit.

Despite the sensitivity of the milk production of these does to climatic or nutritional conditions, the consequences on milk composition were not calculated in the present study and may be the objective of future experiments to obtain more information on the milk production ability of this local Kabylian population of rabbits.

\section{REFERENCES}

Abo Elezz Z., Hassan A., Samak M. 1981. Effect of litter size and mating cycles on lactation in rabbits. Alexandria Journal of Agricultural Research, 29, 7582.

Baselga M., Blasco A., Garcia F. 1982. Parametros geneticos de caracteres economicos en poblarciones de conejo. In Proc.: $2^{\circ}$ Congresso Mundial de Genética Aplicada a la produccion Ganadera, VI. Madrid. Ed, Garci. p : 472. 
Fernández-Carmona J., Alquedra I., Cervera C., Moya J., Pascual J.J. 2003. Effect of lucerne-based diets on performance of reproductive rabbit does at two temperatures. Animal Science, 73: 283-295.

Khalil M.H. 1998. Model for the description of rabbit genetic resources in Mediterranean countries. Application to the Egyptian breeds Giza White and Baladi. Mediterranean Rabbit Working group. 41p.

LeBAS F. 1987. Influence de la taille de portée et de la production laitière sur la quantité d'aliment ingérée par le lapine allaitante. Reproduction Nutrition Développement, 27, 207-208.

Lebas F. 2000. Capítulo I Biología. In: Enfermedades del Conejo. Tomo I Generalidades (Edit Rosell, J.M.) Mundi Prensa Ed. Madrid, pp 55-126.

McNitt J. I., Lukefahr S. D. 1990. Effects of breed, parity, day of lactation and number of kits on milk production of rabbits. Journal of Animal Science, 68, 1505-1512.

Mohamed M.M.A., Szendrõ Zs. 1992. Studies on nursing and milk production of does and milk intake and suckling behaviour of their kits. In Proc.: $5^{\text {th }}$ World Rabbit Congress, Oregon 1992, 708-716.

SAS. 1988. User's Guide. Statistics, Version 6.0. SAS Inst. Inc., Cary, NC.

Zerrouki N., Berchiche M., Bolet G., Lebas F. 2001. Caractérisation d'une population locale de lapins en Algérie : Performances de reproduction des femelles. In Proc.: 9e Journées de la Recherche Cunicole. Paris 28-29 nov. 2001, Itavi Ed. Paris, 163-166.

Zerrouki N., Berchiche M., Bolet G., Lebas F. 2002. Study of prolificacy and its components in a local Kabilian rabbits population in Algeria. In Proc.: $3^{r d} \mathrm{Sci}$ Conf on rabbit production in hot climates, Egypt 2002; 375-382.

Zerrouki N., Bolet G., Berchiche M., Lebas F. 2004. Evaluation of breeding performance of a local Algerian rabbit population raised in the Tizi-Ouzou area (Kabylia). World Rabbit Sci. 13: 29-37. 